\title{
Práticas de re-existências poéticas: a poesia no "busão" em Fortaleza (CE)
}

\author{
Francisco Rômulo do Nascimento Silva ${ }^{1}$ \\ Geovani Jacó de Freitas ${ }^{2}$
}

\section{Resumo}

Este artigo aborda a poesia praticada por Poetas no interior dos ônibus urbanos na cidade de Fortaleza-CE. Como uma das táticas de sobrevivência, a poesia "no busão" cumpre pelo menos dois principais objetivos para os poetas das periferias de Fortaleza e região metropolitana: desmontar os estigmas socialmente cristalizados e sustentar-se financeiramente. A poesia dentro dos ônibus não é algo novo na capital cearense e existe em diversas cidades espalhadas pelo Brasil. Essa prática poética e seus poetas de periferia acena para um novo sentido: não é suficiente resistir. É preciso reexistir para "descolonizar", inventar outras formas de vida: criar é re-existir. Portanto, a primeira reivindicação da re-existência é permanecer vivo em face às "formas contemporâneas de subjugação da vida ao poder da morte", conforme Achille Mbembe, ao falar de uma força colonial-capitalista em sua forma atual como devir-necropolítico-do-mundo. Um jogo de permanentes deslocamentos (fuga) inventivos, planos estratégicos e fugazes de "desaparecimento" e autoafirmação. Seguindo Frantz Fanon, um verdadeiro salto que introduza a invenção na existência, pois "no mundo em que me encaminho, eu me recrio continuamente": uma poética decolonial. Como processo investigativo, utilizamos o aporte metodológico da pesquisa qualitativa, bibliográfica e a experiência etnográfica, com a realização de entrevistas em profundidade e de relatos registrados em diário de campo.

\section{Palavras-chave}

Práticas de Re-existências. Poesia no Busão. Poetas de Periferias.

\section{Abstract}

This article addresses the poetry practiced by poets in urban buses of the city of Fortaleza-CE. As a survival tactic, bus poetry accomplishes at least two main objectives for poets in Fortaleza's and the Metropolitan Area's ghettos: dismantling socially crystalized stigmas and financially supporting

\footnotetext{
${ }^{1}$ Doutorando no Programa de Pós-Graduação em Sociologia, Mestre em Sociologia e pesquisador do Laboratório de Estudos da Conflitualidade e Violência (COVIO) da Universidade Estadual do Ceará (UECE). E-mail: franromulosilva@gmail.com.

${ }^{2}$ Doutor em Sociologia (UFC), professor no Programa de Pós-Graduação em Sociologia (PPGS) da Universidade Estadual do Ceará (UECE) e coordenador do Laboratório de Estudos da Conflitualidade e Violência (COVIO). E-mail: gil.jaco@uece.br.
} 
themselves. The poetry inside buses isn't something new in Ceará's capital and it exists in many cities around Brazil. These poetic practices and their ghetto poets wave to a new meaning: resisting is not enough. It is necessary to re-exist to decolonize, create new ways of life: creating is re-existing. Therefore, the first revindication o re-existing is remaining alive before the many "contemporary forms of subjugation of life to the power of death", according to Achille Mbembe (2017a), when he talks about capitalism in its current form, as the world's-necropolitical-duty (Mbembe, 2014). It's a game of permanent inventive displacements (escape), strategic and quick plans, disappearance, and affirmation. According to Frantz Fanon (2008, p. 189), a real leap that introduces invention into existence, for "in the world through which I travel, I am endlessly creating myself": a decolonial poetics. As the investigative process, we've used the methodological contribution of qualitative and bibliographic research and the ethnographic experience, carrying out in-depth interviews and accounts recorded in field journals.

\section{Keywords}

Practices of re-existence. Bus poetry. Ghetto poets.

\section{Introdução}

Avisa lá pro playboy que quem tomou a vaga dele na faculdade federal fomos nós

Aproveita também e avisa lá pro filhin de papai

Que se ele não aproveitar a faculdade

A favela toma a vaga dele e valoriza bem mais

Avisa lá pro Águia Dourada que nós tamo na faculdade federal e não no programa policial do Barra Pesada

Avisa lá pro PM que me chamou de marginal que qualquer dia eu esfrego na cara dele meu diploma da faculdade federal, pra ele aprender a respeitar as cara, e saber que favelado é intelectual.

Que na minha mochila não tem droga, arma, mas tem livro, estudo, esforço e potencial.

Colégio Farias Brito, primeiro lugar em medicina, só que pra mim não tá dizendo nada. Meu primo também seria se não fosse confundido como bandido e morto pelo demônio de farda.

A poesia pausa, pesa, pisa, pousa e pulsa em cada um de nós.

Só que Jesus é favelado e o diabo é playboy, pois pela paz, eu tirei o pino da granada carregada de amor e joguei. Pra ver quem tem à disposição pra se jogar no amor.

Pra ver quem ouve o clamor da sabedoria, ou quem compreende a dor da periferia.

Dona Maria, eu também preferia, ver os meus, ver os teus, entupindo as 
bibliotecas e ocupando as escolas, do que entupindo as cadeias e ocupando as algemas.

Literatura te tira do tiro da viatura! E eu tô bolado e tô bolando um baseado - só que é o baseado em fatos reais.

São realidades, cidades de desigualdades sociais. Nas favelas, os demônios se vestem de policiais. Nossos abraços são abrigos para os mendigos.

Estou com os esquecidos que cola e fecha comigo.

Que medita e mergulha numa profunda reflexão:

Que todos nós somos seres lactobacilos sujeitos a transformação. Mais ação, mais ação! O repartir do pão é uma ruptura que une e agrega os irmãos. A recuperação de quem sai da prisão é realmente surpreendente. Os loucos prosseguem confundindo os sábios e cobrando inteligentemente. As ruas estão com a gente. $\mathrm{O}$ som da revolução adentrou a mente de um menino, observou. Absorveu com o coração e atingiu o seu espírito.

Tamo no perímetro, cuidado governador Camilo aqui é o fronte: derrubando os muros e com os entulhos construindo as pontes!

Quero ser mais que um espelho ou referência para um menino, eu quero que ele escolha a escola, para refletir o seu destino.

Meu sonho é ver criança com o um livro por baixo do braço e não com fuzil sobre o ombro.

"Mãos pro alto que é um abraço e quem reagir é poesia à queima roupas!" $\mathrm{Eu}$ ando fortemente amado pela minha mãezinha e pela minha coroa, pois foi a minha mãezinha que me ensinou que lugar de mulher não é só na cozinha, mas onde ela quiser, até na advocacia. Sendo Presidente, mais que chefe de família e nenhum machista otário vai passar por cima da dona Maria!

Deixa que eu ensino pra polícia o que é apologia. Eu com diploma na cintura, formado em pedagogia, incitando a educação na mente das criancinha, porque bandido de verdade é o deputado lá em Brasília!

$\mathrm{Eu}$ sou poeta delinquente do sangue quente e a mente fria, fazendo o playboy tremer no calibre da poesia.

E se o moleque me ver cheirando cocaína, ele vai querer cheirar, mas se ele me ver informando, vai tentar estudar. Enquanto não houver educação de qualidade, vai ter promotor de justiça morto pela mão do menor de idade. Ra-ta-ta-ta! O palhaço vai sorrir enquanto o judiciário for bom pro empresário e não pra mim. Deixa eu falar pra ti, de que vale o diploma e a medalha de honra se não respeita as travestis?

Avisa lá pro playboy que quem tomou a vaga dele na faculdade federal fomos nós!

Vocês vão me chamar de Belchior, não por ter sumido, mas por ter cortado a carne de vocês, a carne do burguês. Se prepara playboy que tu é a bola da vez!

Aê deputado, teu choro não me comove, na moral, pede perdão pro meu coquetel molotov. Mas o diabo me quer queimando o playboy como refém no porta mala do carro da BMW, mas minha meta é faculdade, diploma e 
pós-doutorado!

Certa vez, voltando da sala de aula, da minha mochila entrego meu livro na mão do menor e digo: "aê menor, segura esse oitão, mas toma cuidado que os cana tão na quebrada! Nem pensa em trocar bala, porque te quero trocando palavras! E se a polícia perguntar se tu tem passagem, responde que tem passagem na faculdade federal por porte ilegal de inteligência."

Porque eu prossigo incitando o crime: apologia à leitura.

Porque a literatura te tira do tiro da viatura!

A poesia é o pão que alimenta a alma.

Quem não puder contribuir com ajuda, que contribua com as palmas.

Poesia de Jardson Remido, 25 anos, rapper, que é um dos poetas que recita quase diariamente dentro dos ônibus em Fortaleza e região metropolitana, Ceará, Brasil.

A poesia dentro dos ônibus não é algo novo. Final da década 2000 existiu um projeto encabeçado por poetas do Templo da Poesia ${ }^{3}$ chamado "Viagens Poéticas", aprovado pela Secretaria de Cultura de Fortaleza (SECULTFOR), por meio de edital das artes, em 2010. Embora esses e essas poetas ${ }^{4}$ não recebessem ou não pedissem contribuições aos passageiros, a ideia era levar poesias para os ônibus do transporte público coletivo de Fortaleza, com poemas, apresentações e intervenções poéticas dentro dos coletivos e nos terminais. A proposta ainda visava

\footnotetext{
${ }^{3} \mathrm{O}$ Templo da Poesia era um espaço autogerido por poetas que ficou de portas abertas entre os anos de 2006 e 2010 no Centro da Cidade de Fortaleza e agora existe como a Vila de Poetas em Maranguape (cidade vizinha). Fanpage no Facebook disponível em:

<https://www.facebook.com/viladepoetas/> Acesso em: 27 jan. 2019.

${ }^{4}$ Segundo o dicionário on-line de português (https://www.dicio.com.br/poetisa/), significado de "Poetisa" substantivo feminino "Aquela que escreve poesias ou compõe por meio de versos; mulher que compõe poeticamente: 'Marina Colasanti é uma grande poetisa brasileira'. [Gramática] Forma Masculina: poeta. Etimologia (origem da palavra poetisa). Poeta + isa." Entretanto, em campo percebi que a maioria das mulheres que escrevem e recitam poesias, inclusive as que eu entrevistei ou com as quais tive contato nos saraus, se autodenominam "poeta" ao invés de "poetisa". Nina Rizzi, por exemplo, poeta, escritora e uma das organizadoras do Sarau da B1, em entrevista (02 de dezembro de 2018), quando perguntada sobre o porquê de "poeta" e não "poetisa", afirma o seguinte: "a palavra que designa qualquer ofício feito por mulher, ela vem carregada dessa história que é uma história de apagamento, que é a história do patriarcado, que é a história da machismo, que é a história da misoginia. [...] Quando você fala 'poeta' e 'poetisa' é como se fossem palavras colocadas numa balança, né?! E a palavra da mulher ela sempre pesa menos, mas pesa muito pra gente! Então essa palavra 'poetisa' ela vem carregada desse ranço histórico, né?! Dessa história aflitiva, então quando as mulheres passam a requerer para si serem chamadas de 'poetas' e não 'poetisas', elas se colocam em pé de igualdade com o homem. 'Eu sou poeta!' Cecília Meireles já dizia isso há um século! 'Não sou feliz, nem sou triste. Sou poeta!' E muitas outras depois. Tem uma poeta contemporânea muito interessante, que é a Alice Ruiz, ela fala algo que eu adoro, que é 'Se os homens não querem que a gente seja poeta, eles que vão ser poetos' E é isso! Poeta é poeta, né?! Deveria ser algo que ultrapassa o gênero. A palavra escrita alcança outras matizes, né?!" Por este motivo, o substantivo "poeta" será usado para ambos os gêneros neste artigo. Assim como "Poeta" com " $\mathrm{p}$ " maiúsculo para o conjunto dos e das poetas.
} 
a afixar quatro mil adesivos contendo poemas de Poetas da capital cearense ${ }^{5}$.

Foi somente na época das ocupações das escolas em 2016 que alguns Poetas voltam a recitar poesias dentro dos ônibus na cidade de Fortaleza, inicialmente, a partir da necessidade de ajudar na arrecadação de recursos financeiros para a compra da alimentação e produtos de higiene para os ocupantes ${ }^{6}$. Os primeiros poetas a recitarem poesia dentro dos ônibus públicos da Cidade foram Victor Oliveira, Davi (in memória) ${ }^{7}$ e Júnior Scooby (Poeta Marginal), ambos estavam compondo a ocupação da escola Dr. César Cals. Atualmente, são em torno de 80 Poetas de "busão" 8 espalhados pela cidade e região metropolitana de Fortaleza. $\mathrm{O}$ corpo-ocupação é um coletivo multilinear ${ }^{9}$ que se estendeu para além e a partir das ocupações das escolas. Um corpo-ocupação em trânsito da poesia no "busão" e em movimento nos encontros-saraus, slams e bailes de rua que se multiplicavam nos diferentes bairros e comunidades da Cidade.

As ocupações nas mais de cento e cinquenta escolas pelos secundaristas, em 2016, em todo o Estado, não acabaram - ocuparam as mentes. As resistências e reexistências ali não desapareceram - prolongaram-se com o seu valor político e coletivo. Elas se desdobraram em outras formas de ser/fazer nas ruas e dentro dos ônibus. Os meses de ocupação mostraram o que é possível ser e fazer em coletivo.

À semelhança da "sobrevivência dos vaga-lumes", de que fala Didi-Huberman (2011), os e as poetas com suas poesias são como pequenas luzes intermitentes, possuem vocação à iluminação em movimento, sobrevivem, re-existem. Assim como os vaga-lumes não desapareceram, pelo contrário, "alguns estão bem perto de nós, eles nos roçam na escuridão", alguns Poetas se descobriram dentro das ocupações e diariamente recitam poesias dentro dos transportes públicos. Por meio

\footnotetext{
${ }^{5}$ Disponível em: <http:// templodapoesia.blogspot.com/p/viagens-poeticas.html>. Acesso em: jan. 2019.

${ }^{6}$ Os desdobramentos das jornadas de junho de 2013 somados, principalmente, às ocupações dos secundaristas em mais de 175 escolas no estado do Ceará em 2016 e mais de mil escolas públicas em todo o País (2015-2016) contribuíram para a capilaridade e, inclusive, surgimento de novas práticas de resistências juvenis em Fortaleza: saraus, slams, bailes de reggae, rolezinhos e batalhas de MCs. (Conf. SILVA, 2019)

${ }^{7}$ Davi era um dos poetas de busão, como os demais, era jovem e morador da periferia. No momento do assassinato de um colega, Davi estava perto e também foi morto a tiros em junho de 2018.

8 Poetas que recitam em ônibus (coletivo ou transporte público)

9 Trata-se, para Deleuze (1996), de um dispositivo. Mas o que é um dispositivo? É antes de mais uma meada, um conjunto multilinear, composto por linhas de natureza diferente (um rizoma). E, no dispositivo, as linhas não delimitam ou envolvem sistemas homogêneos por sua própria conta, como o objeto, o sujeito, a linguagem, etc., mas seguem direções, traçam processos que estão sempre em desequilíbrio, e que ora se aproximam ora se afastam uma das outras.
} 
da poesia, a maioria deles sobrevivem financeiramente das contribuições voluntárias, partilhando idas e vindas, afetando e sendo afetados.

Segundo Glissant (2011), essa "poética da Relação" é a imagem do rizoma semelhante a uma "raiz desmultiplicada, que se estende em rede pela terra ou no ar, sem que nenhuma origem intervenha como predador irremediável" e "segundo a qual toda identidade se prolonga numa relação com o Outro" (p. 21), abrindo possibilidades de uma escrita poética e política da cultura. Foi durante as ocupações das escolas estaduais em 2016 que acompanhamos o trabalho de alguns dos e das poetas dentro dos ônibus, mas foi somente em 2018 que, além de descrever a "poética do busão", participamos de um projeto de documentário abordando os saraus de periferia e a poesia no busão ${ }^{10}$. Como processo investigativo, utilizaremos o aporte metodológico da pesquisa qualitativa, bibliográfica e a experiência etnográfica, com o uso da realização de entrevistas etnográficas e de relatos registrados em diário de campo (CLIFFORD, 2014; CLIFFORD \& MARCUS, 2016).

\section{Práticas de re-existências poéticas}

Não é suficiente "resistir". É preciso re-existir para "descolonizar"11, inventar outras formas de vida. Portanto, a primeira reivindicação da re-existência é permanecer vivo, face às "formas contemporâneas de subjugação da vida ao poder da morte", conforme Achille Mbembe (2017a, p. 151), ao falar de uma força colonial-capitalista em sua forma atual como devir-necropolítico-do-mundo (MBEMBE, 2014; 2019). Um jogo de permanentes deslocamentos (fuga) inventivos, planos estratégicos e fugazes "desaparecimento" e autoafirmação. Seguindo Frantz Fanon (2008, p. 189), um verdadeiro salto que introduza a invenção na existência, pois "no mundo em que me encaminho, eu me recrio continuamente": uma poética "descolonial".

A poesia no "busão" produz afetos que inventam zonas de re-existências - táticas inventivas que ressignificam a existência, criam "contraespaços" (FOUCAULT, 2013) e subvertem os códigos de dominação, pois os afetos inventam novas

10 “Documentário I Corte 1 I Práticas Poéticas". Disponível em: <https://www.youtube.com/watch?v=WM9PjFVpQnE> Acesso em: 27 dez. 2019, a 01h47min.

${ }^{11}$ Em português e espanhol, há um debate que não existe em francês sobre a distinção entre os termos "descolonizar", mais estabelecido, e "decolonizar", de criação recente. Em francês, o único termo é décoloniser. Embora não se encontre um consenso, pode-se apontar que "descolonizar" tende a se referir ao processo histórico que encerrou o período colonial, enquanto "decolonizar" tende a se referir ao trabalho ético e epistemológico de transcender a situação colonial para uma realmente nova. Devido à falta de consenso, optamos pela utilização do termo "descolonizar" com aspas. 
geografias - um mapa constantemente refeito pela Palavra-Poesia ou por uma Palavra-Praticada (CERTEAU, 1994) nas territorialidades do corpo, assim como nos vai e vem dos ônibus, nas esquinas e calçadas entre os "becos" e "asfaltos" das mentes. Conforme define Achinte (2017), re-existência pode ser compreendida:

[...] como los dispositivos que grupos humanos implementan como estrategia de visibilización y de interpelación a las prácticas de racialización, exclusión marginalización en procura de re-definir y re-significar la vida en condiciones de dignidad y autodeterminación, enfrentando la biopolítica que controla, domina y mercantiliza a los sujetos y la naturaleza. (p. 20).

Neste sentido, enquanto uma das táticas de sobrevivência, a poesia no busão cumpre pelo menos dois principais objetivos para os e as poetas das periferias de Fortaleza e região metropolitana: a) desmontar os estigmas socialmente cristalizados; b) sustentar-se financeiramente:

Então, eu comecei escrevendo poesia e tal, né, tipo saí do grupo, a gente decidiu cada um ir pro seu lado, eu e o Dali, aí comecei a escrever poesia, fui bem sucedido nas ocupações das escolas do Ceará, e eu conheci o Vitinho, o Victor Oliveira, que é "O Malandro" e também conheci o Júnior, que é o "Scooby" e a gente se identificou muito porque a gente tinha uma realidade muito parecida e tal, o Júnior Scooby também puxou FEBEM, também foi pra casa socioeducativa, a gente se conheceu e foram eles que me incentivaram muito porque era novo pra mim esse campo, esse público e tal, eu tinha muita vergonha, bem no começo de me apresentar, tinha a voz trêmula, embargada, ficava meio constrangido e tal de anunciar uma poesia e foram eles que me incentivaram "não, cara, vamos" e eles me incentivaram, acreditaram em mim e eu comecei, comecei. (Jardson Remido, rapper e poeta de busão, entrevista em 16 de maio de 2018).

Os e as poetas de busão "quebram o silêncio" sem pedir licença como em um teatro de rua e fazem do ônibus - este terreno móvel - um palco com o intuito de chamar a atenção e falar de temáticas ligadas às diferentes violações de direitos. Portanto, relatar a partir da experiência cotidiana diferentes situações vividas e, ao mesmo tempo, desconstruir paradigmas cristalizados que servem como justificativas para a perpetuação e o exercício dessas violações são alguns dos objetivos centrais dos e das poetas de busão.

O efeito surpresa dos e das poetas, por si só, provoca instantaneamente medo nos passageiros e, não obstante, um terror, resultado da "experiência compartilhada no cotidiano de violência, seja ela imediata ou no plano da 
iminência" (FREITAS, 2003, p. 103), isto é, o medo de um assalto ou queima de ônibus, esta última provocada por coletivos criminais (facções) ligados ao tráfico de armas e drogas ${ }^{12}$.

Por ser uma interação falada, alguns poetas de busão estabelecem mais ou menos uma lógica de pensamento, um fluxo de fala e um tipo de atenção visual representativo do encontro durante uma intervenção dentro do coletivo. Isto é, "uma ocasião de fala ou episódio de interação" que, inclusive, envolve riscos de diferentes possibilidades. Pode, por exemplo, comprometer tanto o poeta como aqueles a quem se dirige a mensagem dentro do ônibus, "num certo sentido coloca todos os presentes em perigo". Alguns poetas narram casos de insultos, de passageiros mandar calarem a boca, inclusive: "o orador se abre à possibilidade de que os receptores pretendidos o insultarão não prestando atenção a ele, ou pensando que ele é atrevido, tolo ou ofensivo pelo que disse" (GOFFMAN, 2011, p. 43-45).

Quando a gente terminava, o povo lá, os moradores, ficavam assim, perplexos, admirados, porque eles imaginavam tudo, imaginavam que a gente ia assaltar, que a gente ia fazer o fuzuê, que a gente ia fazer baderna, imaginavam tudo, imaginavam que a gente ia tacar fogo no ônibus, só não imaginavam que a gente ia falar de poesia, de educação, de literatura. (Jardson Remido, rapper e poeta de busão, entrevista em 16 de maio de 2018).

Os poetas de busão ressignificam e atribuem outros sentidos aos transportes públicos por meio das intervenções com a poesia. Escrevem e decoram poemas autorais com temáticas ligadas à favela, ao racismo, à violência policial, à homofobia e denunciam, por meio da performance e do inesperado, a construção midiática e social do perfil "bandido", "perigoso", "ignorante" atribuídos a determinados sujeitos.

A artista de rua e poeta marginal Chris Rodrigues, 26 anos, negra, andrógino não binário, é também uma das poetas de busão. Nasceu e se criou em uma localidade chamada Mangueira, na Comunidade São Miguel, Grande Messejana, em Fortaleza. Em 30 de junho de 2018, Chris esteve no Sarau da B133, aquela era a

\footnotetext{
12 Disponível em: <https://www.opovo.com.br/noticias/fortaleza/2019/01/onibus-saoincendiados-em-ataques-registrados-em-fortaleza.html> Acesso em: jan. 2019. Para "facções no Ceará", ver Barros et al. (2018); Sá e Aquino (2018) e Paiva (2019).

${ }^{13}$ Sarau da B1 - evento realizado uma vez por mês, desde 2015, e que leva esse nome por acontecer em uma das Praças da Avenida Bulevar 1, n 121, no Conjunto São Cristóvão, coração comercial de um dos bairros mais pobres da capital cearense, o Grande Jangurussu. Disponível em:
} 
sua primeira vez no ano naquele espaço.

Em entrevista, Chris relata que começou a se engajar em movimentos sociais após a chacina da Messejana, que aconteceu dia 12 de novembro de 2015 e vitimou onze pessoas, dentre elas, dez jovens entre 15 e $29 \operatorname{anos}^{14}$. Disse que em 2016, "por imitação" e por já ter contato com o rap, começou a recitar poesias no busão.

[...] eu não tinha o dinheiro pra pagar a passagem, só pra comer, tava indo pro Cuca. Eu falei "cara, eu tenho que chegar no Cuca", não vou pular catraca, eu tinha feito umas rimazinhas a noite passada e eu vou fazer a rima. Era no papel, não era nem decorado. Quando eu fiz eu pedi a passagem, sempre fui muito carismática assim, performática, eu sou escorpião com ascendente em áries, então eu sou o exagero dos exageros, você me conhece, não deixo barato mesmo, querida, deixo caro pra eles sentirem no bolso [ri] fiz a poesia, ganhei a passagem, ganhei 15 conto, a galera me aplaudiu, foi a primeira vez e de tudo que eu ganhei o mais massa foram os aplausos e aí eu me viciei. Dia 16 agora desse mês que vai vir, junho, fez dois anos de poesia no busão. (Chris Rodrigues, artista de rua e poeta de busão, entrevista em 30 de junho de 2018)

Não diferente de muitos poetas de busão, a presença por si só de Chris dentro dos ônibus, em suas palavras, é motivo de "choque" para os passageiros. À pergunta como é a experiência de recitar dentro do ônibus, visto que ela não é uma "poeta normativo", ela respondeu:

Comum, um poeta comum, né. Um poeta comum que os motoristas estão acostumados a deixar subir nas topiques por trás e nos busão que é onde a galera vai, os boy que faz poesia e rap, só que como eu digo na minha intervenção, é pra destruir a cena, não é pra desconstruir, é pra destruir a cena de um rapper de Fortaleza aqui, porque a cena de Fortaleza, a cena do Brasil, é majoritariamente ocupada por homens heteronormativos padrão e tal, mas que representa, mas só naquele padrão, mas aí chega uma bicha andrógena, não binária, completamente misturada, características de homem, perna cabeluda, barba, roupa de mulher, bigode com batom, se liga, é um choque que... seguido da minha intervenção na poesia faz a pessoa repensar se realmente é tudo que ela foi ensinada tá certo, se ela não foi ensinada com ignorância, com autoritarismo, com intolerâncias, aí ela vai só repassando o que ela

<https://www.facebook.com/romulofilosofo/videos/2294897197206889/> Acesso em: nov. 2018.

14 Evento foi amplamente repercutido pelos media na Cidade. Disponível em: $<$ https://diariodonordeste.verdesmares.com.br/editorias/seguranca/chacina-de-messejana-comotudo-comecou-1.1592831 > Acesso em: nov. 2019. 
aprende dentro de casa, se liga? (Chris Rodrigues, artista de rua e poeta de busão, entrevista em 30 de junho de 2018)

É no próprio terreno móvel do vai e vem nos ônibus, no caminhar cotidiano pela Cidade que o corpo dos e das poetas fala. Não é a poesia de Chris que chega primeiro, mas seu próprio corpo. As reações às suas roupas coloridas, tinta branca no corpo, "batom no bigode" são diversas, desde o olhar de surpresa e desprezo até reações bruscas como agarrar a bolsa, esconder o celular.

Após relatar que em abril de 2018 foi gravemente espancada por um homem que quase quebrou o seu pescoço de tanto esmurrá-la - "fiquei entre a vida e a morte, se liga?" -, disse que uma das experiências que mais marcou no "busão" foi quando saiu do Hospital São José, local que ficou internada após a tentativa de assassinato.

Foi do dia que eu saí do hospital, eu tava com a minha mãe, ela me levou bermuda da Nike e uma blusa gola polo, eu já tava me sentindo muito masculino por causa do cabelo que eu tinha cortado e por causa dos antibióticos tava caindo meu cabelo, aí cortei, ela chegou com uma roupa de homem, porque ela tem vergonha, tinha. Não que ela tinha vergonha, acho que ela tinha muito medo de eu ser agredido, então ela ficava naquela bad, "mãe, eu vou fazer poesia", "você não é doido de fazer isso, uma vergonha dessa", aí eu peguei e disse "vou te mostrar que a partir de agora eu sou uma artista" e comecei a rodar. Aí eu entrava "boa tarde", no Parangaba/Francisco Sá, só playboy, foi super lindo, uma interação cheia de risadas, gargalhadas, eu fiz uma palhaçada, uma baixaria dentro do ônibus, se liga? A galera parou e ficou "não acredito nesse menino", sabe? Aquilo foi lindo, eu só via a minha mãe com a mão na boca assim, ó. Pasmada! e os olhos brilhando e o povo me dando dinheiro, dinheiro e tome moeda, ela não acredita naquilo que eu tava fazendo. Quando chegou na Parangaba eu achei que ela ia falar, né, "meu filho, me perdoe por tudo que eu falei, não tinha noção, não tinha noção do que você fazia dentro do ônibus, é tão lindo, tão maravilhoso, as pessoas deixam o celular de lado pra ficar olhando pra você, tira os fones pra lhe ouvir, nunca na minha vida... eu tenho que lavar dez enfermarias, todas sujas", aí eu falei "a senhora é boa pra zelar, eu sou boa pra animar, pra fazer feliz, mãe, é o que eu quero", "eu dou total apoio, porque você é um artista", aquilo ali foi impagável, foi a experiência, da minha mãe ver a minha vida, porque isso é a minha vida, tanto que eu tô há 29 dias sem uso de drogas, só de maconha, eu tô morrendo de abstinência, mas a maconha tá controlando, sem droga de comprimido, mas tô bem. Tô bem pra caralho. (Chris Rodrigues, artista de rua e poeta de busão, entrevista em 30 de junho de 2018). 
O risco cotidiano assumido pelos poetas de caminhar pela cidade, de recitar dentro dos ônibus como pessoa singular não é descartado, muito pelo contrário. Caminhar como categoria social, segundo Judith Butler (2018, p. 59), "atravessa esse jeito de andar e essa caminhada particular, esse movimento singular no mundo; e se há um ataque, ele visa o indivíduo e a categoria social ao mesmo tempo". O ato de circular pela Cidade com a poesia dentro dos ônibus, na condição de poeta de lugar nenhum, abre possibilidades de ocupar espaços na mente alheia, o itinerário pode estar fechado, mas os afetos estão abertos. A "descolonização" começa de dentro para fora.

A potência das sobrevivências dos e das poetas de busão passa pelo desejo de desmontar os estigmas socialmente cristalizados, ou seja, nas palavras de Chris: "provocar nas pessoas o questionamento sobre se o que elas aprenderam é mesmo verdade" e, ao mesmo tempo, sustentar-se financeiramente.

\section{A Poesia no "busão" como trabalho imaterial afetivo}

O número de Poetas recitando nos ônibus tem crescido. São histórias de vida que recitam relatos em forma de poesias não somente nos saraus que acontecem nas favelas e periferias, mas também dentro dos ônibus que circulam pela Cidade. Posturas políticas, semelhantes a estas, constituem a trama dos viventes e os dispositivos urbanos que envolvem práticas de re-existência, de questionamento e sobrevivência ao neoliberalismo (CERTEAU, 1994; ACHINTE, 2009; 2017; MBEMBE, 2017a).

Práticas cotidianas, conforme Michel de Certeau (1994), são "maneiras de fazer" pelas quais os agentes sociais se apropriam criativamente do espaço social. No caso deste artigo, referimo-nos aos e às poetas que fazem o seu ofício de mostrar a sua poesia dentro do ônibus urbano, o "busão", destacando seus relatos e formas de sobrevivências que, aproveitando-se das lacunas deixadas pelo padrão social ou até mesmo sob máscaras de aparente reprodução da ordem, transgridem, agitam ou estabelecem outras formas de organização social por meio da apropriação do espaço-móvel dos ônibus, assim como a subversão da lógica, inventando reexistências.

Os transportes públicos em Fortaleza têm sido um dos principais espaços de trabalho para os vendedores ambulantes. Diferentemente dos poetas de "busão" que não oferecem um produto físico, esses vendedores oferecem diferentes acessórios (carteiras, canetas, bolsas, fones de ouvidos e acessórios para celular e eletrônicos), aperitivos (bombons, biscoitos, amendoins etc.), cosméticos (sabonetes, cremes e produtos caseiros e medicinais), vendas geralmente 
acompanhadas pelo discurso religioso judaico-cristão, relatos de abstinência causada pela dependência de substâncias psicoativas, geralmente seguidos de propagandas de "Casas de Tratamento". Segundo esses mesmos vendedores, sem ajuda do Governo e sem fins lucrativos, os discursos se repetem em seu conjunto como ações autônomas: "este é o fruto do meu trabalho. É com este humilde trabalho que tenho dado 'tapa na cara' do desemprego!"

Mas também há os que chamamos de "vendedores "precários'" de "busão". Trata-se daqueles e daquelas que, geralmente, pedem contribuições voluntárias aos passageiros para comprar em estabelecimentos de bomboniéres ${ }^{15}$ e, após conseguir completar a "cota", compram caixas de chicletes ou pastilhas refrescantes, sacos de pipocas, bombons ou de amendoins e circulam nos ônibus vendendo.

Telles e Hirata (2007, p. 174) tomaram de empréstimo a metáfora "a cidade como bazar" para "descrever as interseções entre os mercados formais e os mercados informais, ilegais ou ilícitos" na cidade. Segundo os autores, esses "trabalhadores precários" transitam em "fronteiras porosas entre o legal e o ilegal, o formal e informal em que caminham, de forma descontínua e intermitente, as figuras modernas do trabalhador urbano, lançando mão das oportunidades legais e ilegais que coexistem e se superpõem nos mercados de trabalho." A fronteira entre os perfis de "vendedores ambulantes" e "vendedores 'precários"' é incerta. Geralmente, em sua maioria, jovens negros entre 15 e 29 anos, sexo masculino, moradores de periferias e favelas, disputam o espaço e a clientela dentro dos ônibus.

Vender nos ônibus requer mais que oferecer um produto e conseguir vendê-lo, conforme Perelman (2017), os/as vendedores/as ambulantes que trabalham dentro dos "busões" procuram criar e manter relações com outras pessoas, além de construírem território que lhes é próprio: "a venda ambulante implica comportamentos específicos na relação com o motorista, com os passageiros e com outros vendedores, bem como requer a construção de uma territorialidade (espaço e tempo) específica e necessária para poder oferecer os produtos" (PERELMAN, 2017, p. 70).

É dentre essas fronteiras incertas que a poesia no busão se distingue e se assemelha aos "vendedores ambulantes" e aos "trabalhadores "precários". Assemelha-se, pois a poesia no busão é considerada pelos poetas como uma fonte de

\footnotetext{
15 Bombonieres são estabelecimentos que vendem doces, acessórios e conveniência. Geralmente, os vendedores nos ônibus compram pipocas, chicletes, doces em quantidade (sacos ou caixas contendo dezenas) dentro dos terminais urbanos de ônibus.
} 
renda, uma atividade laboral - um "corre" pela sobrevivência ${ }^{16}$. E se distingue por ser um trabalho imaterial afetivo.

A poeta Gabriele Gaia, 22 anos, nasceu em Curitiba (PR) e hoje mora no Bairro da Serrinha, em Fortaleza. B-girl e participante de Batalhas de MCs, ambos elementos do Movimento Hip Hop ${ }^{17}$, passou a recitar poesias no busão em Fortaleza para se sustentar e sustentar seu filho. Por ter participado de batalhas de MCs e já escrever poesias há algum tempo, assim como boa parte dos poetas da periferia, Gaia trabalha recitando dentro dos coletivos há quase dois anos.

Muita gente desacredita do corre e acha que não dá em nada, mas pra você que tem esse pensamento, mano, pêdo! Tá ligado? Porque dá sim! Ontem em menos de cinco horas eu fiz 150 reais. Meu, eu vou querer trampo fixo pra quê?! Pra ganhar 35 reais trabalhando oito horas? Sem contar que, tipo, eu gosto de fazer isso, tá ligado?! Eu dô mó valor e tipo: eu ganho muito mais, eu tenho muito mais tempo pra mim e pro meu filho e não tem burocracia, velho! Eu posso ir com a roupa que eu quiser, usar os pano largo que eu dô mó valor. Aí tipo, negócio de "passar dificuldade". Mano, quem é que não passa dificuldade, véi?! Todo mundo passa! Porém, minha vida tá rocheda, véi! Eu pago minha contas, eu crio o meu filho, eu faço minha compras e ainda sobra dinheiro, doido! (Gabriele Gaia, poeta de busão, 20 anos, via status instagram, no prelo)

A sociologia do Trabalho Imaterial, desenvolvida por Hardt e Negri (2001, p. 311), define "trabalho imaterial" como aquele que produz "um bem imaterial, como serviço, produto cultural, conhecimento ou comunicação". Os autores dizem que existem duas faces do trabalho imaterial: uma em analogia com o funcionamento de um computador que "tende progressivamente a reduzir as práticas e relações de produção, juntamente com todas as práticas e relações sociais" e a segunda face como o trabalho imaterial afetivo: "Esta segunda face do trabalho imaterial, sua face afetiva, vai além do modelo de inteligência e comunicação definido pelo computador. [...] o que o trabalho afetivo produz são redes, formas comunitárias, biopoder." (idem, p. 314). A poesia no "busão" aproxima-se, portanto, a um trabalho imaterial afetivo. Além da comunicação, isto

${ }^{16}$ Conforme a poeta e estudante Patrícia Alves, 19 anos, trata-se do "corre obrigatório pelo capital", isto é, luta cotidiana para sobreviver dentro do sistema.

17 "[...] ainda hoje o universo hip hop é marcado pela reflexão e crítica que faz em relação às desigualdades sociais e raciais por meio da poesia, dos gestos, falas, leituras, escritas e imagens que tomam forma pela expressividade de quatro figuras artísticas, a saber: mestre de cerimônia - MC, disc-jóquei - DJ, dançarino ou dançarina - b.boy ou b.girl e grafiteiro ou grafiteira." (conf. SOUZA, 2009 , p. 21) 
é, contato visual e escuta, a poesia recitada no ônibus envolve afeto.

Porque pra sociedade favela não tem sentimento, favelado é oco, a gente não tem sentimento e a gente provou que a gente transborda, a gente é cheio, tão cheio que a gente tem que compartilhar, transmitir isso, e a gente quebrou perspectivas, né, a gente subjugou as expectativas da galera, que a galera achou que a gente ia queimar ônibus, assaltar, só que a gente só tomou de assalto a atenção e matou a ignorância, é o que a gente chama de latrocínio intelectual, né? E a gente começou e "cara, isso daqui dá certo e tal" e a gente também falou "ô, mano, a gente em que também valorizar o nosso trampo" e a gente começou a pedir colaboração e tal, "quem puder colaborar e tiver disposição no coração a gente aceita e tal" e a galera começou a colaborar, a galera começou a apoiar muito, acreditar muito, e incentivar "continue assim" e tinha gente que se abria, que falava, assumia, "olha, eu vou confessar que eu pensava que vocês iam assaltar, que vocês iam mandar a gente ir pra fora do ônibus, que iam incendiar o ônibus" a gente acabou incendiando o coração, como o Sérgio Vaz fala "fazer fogueira nos corações, incendiar os corações" e hoje em dia têm muitos poetas que estão ocupando os ônibus, a gente tá ocupando vários espaços, mano, vários setores. (Jardson Remido, rapper e poeta de busão, entrevista 16 de maio de 2018).

Os temas e performances variam de poeta para poeta. Trata-se de um corpo particular, pois é na noção de performance que "encontraremos sempre um elemento irredutível, a ideia da presença de um corpo" (ZUMTHOR, 2018, p. 38). Corpos que abordam geralmente temas estruturais, por exemplo, o racismo, o machismo, a desigualdade social; outros falam sobre o cotidiano, a favela, a injustiça, o Estado, os desafios que a vida impõe; e há aqueles que falam sobre amor, esperança, gratidão pela vida. Em entrevista, Gabriele Gaia falou um pouco sobre como os afetos ou "atenção" são mobilizados por meio da poesia.

Quando eu fui pros ônibus eu comecei a fazer umas poesias e percebia que nem todo tipo de poesia que eu recitava agradava a galera. Poesia que é muito afrontosa, se liga? A maioria dos caras que faz poesia, eles fazem poesia que afronta a galera e a galera já se sente mais retraída. Eu não acho... eu não acho... como é que é, como posso dizer? [não tenho nada contra a poesia que bate de frente, entendeu, com o sistema, com a atitude da galera], mas pra você ser bem recebido, você tem que ir na humildade, tem que ir na mansidão, porque quando você vai muito afrontoso, a galera não te recebe bem, se liga? Então eu comecei a perceber isso. Se eu começasse a fazer umas poesia que começasse a não afrontar a galera, mas mostrar a ela as coisas que a sociedade vem mostrando, as coisas que ela vem fazendo de errado de uma forma mais carinhosa elas iriam receber melhor do que já 
chegar afrontando, entendeu? Então, o público jovem ele gosta dessa afronta, mas o público mais velho não gosta disso, entendeu?! [...] Eu comecei a perceber isso pela atenção que não me davam. Entendeu? Pela atenção. Tem muita gente que quando você recita uma poesia; fone de ouvido, não olha pra você, começa a conversar com outra pessoa, isso é um sinal de que a pessoa não tá nem aí pro que você tá falando, não tá gostando, entende?! Agora quando eu comecei a lidar com o público, que eu comecei a perceber que tem certos tipos de poesias que chamam atenção e outras não, eu comecei a fazer as que chamavam atenção. Aí eu percebi que a galera prestava atenção, já me escutava, já deixava de conversar com a pessoa do lado pra me ouvir, e é isso que diferencia. (Gabriele Gaia, poeta de busão, entrevista em 31 de maio de 2018).

São vários os fatores que podem beneficiar ou não a escuta e a interação dos passageiros com a poesia ou poeta. Importante é observarmos a centralidade de como os afetos são mobilizados estrategicamente dentro dessa experiência. Embora muitos poetas saibam o que falar e fazer previamente, eles também sabem que a imprevisibilidade dentro do ônibus torna cada experiência única: "Poesia pra mim, mano, dentro do coletivo, é conhecimento, experiência de vida, ser coletivo. E todo coletivo você vai sentir frio na barriga por não saber o que vai acontecer", disse o poeta Scooby quando perguntado sobre o que é o fazer poético no busão.

Para os poetas de busão cada experiência é uma oportunidade única de fala, escuta e de sustento. Mas também de compartilhar histórias de vida. Geralmente são poemas-relatos, uma confissão pública, uma memória coletiva, afetiva e individual, enfim, um diário particular tornado público por meio da oralidade. Um dos poemas de Gabriele Gaia relata a sua história de vida. Trata-se de um poema, segundo Gaia, que não chamou muita atenção dos passageiros e por esse motivo ela parou de recitá-lo:

\section{VIVÊNCIAS}

Aí mãe, vinte anos de idade, não fiz nenhuma faculdade nem dei orgulho pra família.

Pulei o muro da escola e, segundo a sociedade, sai da trilha.

Não tive ninguém pra me espelhar e me ensinar a andar na linha.

Por isso eu decidi a escrever minhas próprias linhas.

Eu sou poeta marginal. Autônomo em história autoral.

Não quis ser médica, advogada nem nada disso.

- Aí, mãe, foi mal!

Preferi viver da arte. Maus olhares e julgo da sociedade?

Faz parte!

Seja bem sucedido, morra de trabalhar, se estresse e ganhe um milhão, 
depois morra de um infarto.

Não tenha tempo pra família, só para a empresa.

Dos filhos? Se esqueceu!

Vai achando que as notas que você deixar na conta vai preencher o amor que você não deu.

Cresci sem pai. Não é novidade. Cotidiano é hereditário.

Criar vai além de grana. $\mathrm{O}$ afeto não é monetário.

Aborto paterno. Esse sim, ó: legalizado!

Abandonam suas crias e é com o aval do Estado.

E a mina? Que se dane! Quem mandou abrir as pernas?

Até parece que fez sozinha

sem nenhuma ajuda paterna.

É complicado, a hipocrisia é muito sem parentesco,

como diz o ditado: "pimenta no dos outros é refresco!"

Mas meu caso, ó, foi diferente:

foi pai e mãe ausentes.

E não tem nada que te deixe mais doente

que o abandono dos parente.

Mas sigo firme e forte, guerreira!

Garra vem de raiz.

Se a ferida tá aberta, eu mesmo a costuro!

E o troféu, ó: cicatriz!

Se eu cair oito, chapa. Levanto nove!

Pra te mostrar que o sexo não é frágil

e o instinto aqui é forte!

Então, muito cuidado ao pisar na minha aldeia.

Me jogaram aos lobos e eu voltei liderando a alcateia.

Porque desde o princípio eu disse que não ia me entregar.

Postura reta por caminhos onde eu sempre tive tudo pra entortar.

E eu cresci com vários dizendo que eu tinha que ser alguém

Mas na real: "Quem falou pra você que eu não sou ninguém?"

Quem falou pra você que você não é ninguém?

Eles querem enfiar na tua cabeça que você só vale o que você tem.

Você só vale o que você tem? Não! Mentira!

Estratégia do sistema tentando te pôr na mira!

Tentando te encaixar nesse padrão.

Menor tentando se encaixar hoje está preso

ou, infelizmente, a sete palmos desse chão!

Você vale o que você tem? Não!

Você vale o que você é!

Mantenha a sua postura e nunca perca a sua fé.

Os poemas criam determinados afetos que servem como arma para os e as poetas pela sobrevivência não somente individual, mas também coletiva. Não há 
receita pronta, existe a experiência em si, a escolha política de chegar sem aviso prévio dentro dos ônibus e erguer a voz e agir a favor da vida. No final da entrevista, após dar um beijo em seu filho de apenas quatro anos, Gabriele Gaia disse que tinha medo do incerto e que para ela o futuro é assustador.

Assim como Gaia, o poeta Júnior Scooby, em entrevista, diz que a poesia é que o sustenta. É por meio da poesia no busão que ele consegue pagar o aluguel, se alimentar e pagar as contas. É cada vez maior o número de poetas que fazem poesia no busão para sobreviver financeiramente. Eles não são considerados "trabalhadores" propriamente ditos.

Além de circularem dentro dos ônibus, a maioria atravessa a Cidade por meio do uso dos terminais urbanos de ônibus. Nesses espaços, geralmente, eles e elas conseguem denunciar as diferentes formas de opressão sofridas histórica e cotidianamente, assim como ganhar algum trocado (dinheiro) de passageiros após recitar poesias - mesmo correndo o risco de sofrer racismo institucional pela Guarda Municipal de Fortaleza (GMF) dentro dos terminais de ônibus, como aconteceu em junho de 2017 com os poetas Júnior Scooby ${ }^{18}$ e "Pardal", no Terminal do Siqueira (SER V ${ }^{19}$ ).

Vidas descartáveis, não passíveis de luto, nasceram e se criaram em "espaços precários" (AGIER, 2015), alguns dos poetas possuem histórias de inúmeras violações "provocadas por tantos incríveis sofrimentos" resultantes de múltiplas consequências da potencial fusão do racismo e do capitalismo: pobreza extrema, pais mortos ou dependentes químicos, violência doméstica, tráfico de drogas, abandono, situação de rua, medidas socioeducativas, egresso do sistema carcerário, criminalização, sentimento de inferioridade, "objecto de humilhação numa humanidade supérflua, entregue ao abandono, que já nem é útil ao funcionamento do capital" (MBEMBE, 2014, p. 14) e outros traumas estruturais e psicológicos indizíveis, ambos frutos de uma degradação histórica "mais sempiterna que um apocalipse" 20 (GLISSANT, 2011, p. 17) e "quinhão de todas as

18 "Com armas de choque, Guardas Municipais agridem jovem em terminal de ônibus em Fortaleza". Disponível em: <https://www.youtube.com/watch?v=svlkh83T2mQ> e na reportagem do Programa CE TV “Guarda municipal agride homem no Terminal de Ônibus do Siqueira”. Disponível em: <http://g1.globo.com/ceara/cetv-1dicao/videos/v/guarda-municipal-agride-homem-noterminal-de-onibus-do-siqueira/5960624/> e "Júnior Scooby fala sobre abordagem agressiva de guardas municipais terminal Siqueira Fortaleza 2017". Disponível em: <https://www.youtube.com/watch?v=k_WzGnk0QNE>. Acesso em: 04 mar. 2018 às 00h02.

${ }^{19} \mathrm{~A}$ administração executiva da Prefeitura de Fortaleza está dividida em subprefeituras chamadas de Secretarias Executivas Regionais (as SERs), que são ao todo 7 (SER I, SER II, SER III, SER IV, SER V, SER VI e a regional do Centro. Cf. https://pt.wikipedia.org/wiki/Lista_de_bairros_e_divis \%C3\%B5es_de_Fortaleza. Acesso em: 02 set. 2018.

${ }^{20}$ Glissant (2011, p. 17) narra a petrificante experiência da deportação dos africanos para as Américas. 
O poeta ele sabe qual é a necessidade da poesia. Pois eu percebi que a minha necessidade era apenas fazer poesia dentro do coletivo, porque eu tinha que pagar o meu aluguel, porque eu tinha que pagar a minha luz, porque eu tinha que me alimentar senão eu passava fome. Quem me alimentava, quem me dava moradia é a poesia! Quem me dava alimentação é a poesia, quem fez eu adquirir todas as palavras, quem fez eu conhecer as pessoas da faculdade... é a poesia! [...] Uma senhora uma vez me chamou de "preto, vagabundo, sem futuro!" Aí eu com todo o ódio do mundo, né, fiquei: "pô, eu não sou preto, eu não sou vagabundo, eu não sou sem futuro!" Aí eu, porra! [porque eu tinha a ideologia antes disso. Antes de quebrar essa crítica eu tinha outra ideologia, quando ela me chamou de preto, vagabundo, sem futuro, eu tinha a ideologia que eu era pardo] Porra, que viagem! E eu só me calei, né, quando ela me chamou de preto, vagabundo, sem futuro, só me calei e disse assim: “que a paz habite em teu coração, valeu!” E eu tava com ódio! E se eu não tivesse dentro do coletivo eu tinha batido nela! Porque eu tava aprendendo ainda a fazer poesia e tem que escutar que eu sou "preto, vagabundo, sem futuro!" A fome quando fala. Por isso que eu digo que tem que ser alimentação. A fome [porque eu tava com fome] falou mais alto. Eu disse: “Quem tiver gostado, muito obrigado. E você que não gostou [né, porque eu queria quebrar o ego dela] pra você que não gostou e queria contribuir eu lhe agradeço desde já!" Aí todo mundo veio contribuir, né?! Aí eu desci do busão e agradeci, "muito obrigado, boa tarde aí!” Aí quando eu desci do busão eu comecei a esmurrar o poste! Porque eu tava com muito ódio dentro de mim. "Porra! Que droga! Eu tô fazendo o que eu amo, não tô fazendo nada de errado e as pessoas vêm me criticar! Aí foi o momento que quando eu comecei a pensar no que ela falou e eu tinha que conversar aí, ter esse diálogo com as pessoas de ser "preto, vagabundo e sem futuro". Eu comecei a pensar nessas palavras, né?! (Júnior Scooby, poeta de busão, entrevista em 21 de maio de 2018).

Ao mesmo tempo, nessa relação de uma existência enclausurada em uma lógica do recinto fechado (MBEMBE, 2014), além da poesia no "busão", muitos dos e das poetas disputam espaço no mercado de trabalho formal e informal ou estão à procura de emprego, alguns (poucos) estão na universidade ou possuem nível superior de ensino, estes últimos geralmente não são os mesmos que fazem poesia

O terror inaugural e indizível da barca (Navio Negreiro): "imaginem duzentas pessoas amontoadas num espaço que mal poderia conter um terço delas. Imaginem o vómito, a carne viva, os piolhos pululantes, os mortos jacentes, os agonizantes apodrecendo. Imaginem, se forem capazes, a embriaguez vermelha das subidas ao convés, a rampa que é preciso subir, o sol negro no horizonte, a vertigem, esse deslumbramento do céu colado às ondas. Vinte, trinta milhões de deportados durante dois séculos ou mais." 
no busão.

La narrativa de nuestro sistema educativo transita por construir subjetividades que se acomoden a estos preceptos de la modernidad, en ese sentido la estabilidad como principio se aprende a la par de las letras del alfabeto. Nos educaron para alcanzar el éxito y en consecuencia garantizarnos un futuro próspero distante de cualquier atisbo de inseguridad que colocara en riesgo la única posibilidad de vida. Sin embargo, paralelo a este discurso de la estabilidad el acecho de su contrario fue inoculando en nosotros los temores a perderla, así quedamos atrapados entre el deseo de seguridad laboral y el miedo al desempleo, la necesidad de tener una pareja permanente y el miedo a la soledad, el sueño de una vida determinada por obtener buenos ingresos y el miedo a la precariedad económica, el prestigio social alcanzado por la vía de ser un profesional y el miedo a no lograr las metas impuestas o auto-impuestas y, la apuesta por una vida emocionalmente equilibrada y el miedo a perder la razón. (ACHINTE, 2009, p. 448-449).

O discurso da estabilidade financeira somado à ideia de "sucesso" e "ser bemsucedido" tornaram-se princípios que obrigam os sujeitos a se sentirem bem em um "mundo que pressiona e desqualifica" se alguém desvia da rota de consumo. "Mantener el equilibrio es la norma con la cual se establece el rasero que acepta o rechaza, legitima o intimida, reconoce o discrimina." (ACHINTE, 2009, p. 449, grifamos).

Alguns dos poetas pararam de estudar no ensino básico pelas mais diversas razões e estão fora do mercado formal ou informal de trabalho; já outros dependem de algum parente para sobreviver e existem aqueles que já trabalharam no varejo do mercado de drogas ilícitas, além de outros que estão ou já estiveram em situação de rua.

Porque tem moleque desses aí que tá ganhando grana, por exemplo, fazendo poesia dentro de ônibus. O moleque sai do crime e vai fazer poesia dentro dos coletivo e consegue ganhar a grana dele pra ele se manter; comprar a roupa dele, se alimentar, ajudar em casa. Tem outros que vão pro sinal fazer malabares, tem outros que já cantam rap e consegue ganhar uma grana com isso. Então assim, esses jovens estão vendo que podem fazer aquilo que eles gostam, podem ganhar a grana deles e não precisam mais entrar no crime, que o crime... e eles entendem que o crime é apenas uma forma que o sistema tem de executar eles, né?! (Carlos Melo, poeta e um dos organizadores do Sarau da B1, entrevista em 14 de fevereiro de 2018).

De acordo com Mbembe (2017b), o capitalismo neoliberal tem deixado "em sua 
esteira uma multidão de sujeitos destruídos, muitos dos quais estão profundamente convencidos de que seu futuro imediato será uma exposição contínua à violência e à ameaça existencial". Comparado ao escravo do sistema de plantação (plantation), o escravo moderno é resultado de uma tripla perda: "a perda de um 'lar', a perda de direitos do corpo de cada um, ou de cada uma, e a perda de um estatuto político" (MBEMBE, 2017a, p. 122). É nesse sentido que o filósofo pensa o capitalismo na contemporaneidade como processos necropolíticos: formas de "subjugação da vida ao poder da morte" (idem, p. 151).

Achille Mbembe (2014), ao apresentar sua tese $O$ devir-negro do mundo ${ }^{21}$, afirma que o nome "Negro" deixou de remeter unicamente para à condição atribuída aos seres de origem africana - sem deixar de discutir questões de identidade, alteridade e superação da diferença. O autor afirma que existe um "novo caráter descartável e solúvel" que criou processos de sujeição e precarização da vida em nível global, originando experiências de subjetivação de uma escravidão moderna, "pois o escravo não é um sujeito de direito mas uma mercadoria como todas as outras." (MBEMBE, 2017a, p. 35).

Ou seja, para Mbembe (2014), pela primeira vez na história, devido à "potencial fusão do capitalismo e do animismo", o nome Negro deixa de remeter unicamente à condição atribuída aos genes de origem africana, durante o primeiro capitalismo, e passa a ter o "novo caráter descartável e solúvel, à sua institucionalização enquanto padrão de vida e à sua generalização ao mundo inteiro" (p. 18). Além de um "abuso que constitui a essência" do que Rolnik (2018, p. 77) chama de "tradição colonial capitalística" de uma vida "cafetinada", o "atual" capitalismo financeiro produz seres que são separados pelas categorias "úteis" e seu inverso, "inúteis", homens e mulheres que viraram sujeitos-plástico, digitais, capturados por um código e, em seu "processo sangrento de devoração", depositaram uma confiança destruidora na inteligência artificial de movimentos líquidos operacionada em milésimos de segundos (Bolsa de Valores), concomitantemente, esta, por sua vez, descarta irreversivelmente a vida dos seres e das espécies. Neste sentido, o capitalismo em sua soberania necropolítica fabrica "uma massa de gente habituada a viver no fio da navalha ou, ainda, à margem da vida - gente para quem viver é

21 O "devir-negro do mundo", portanto, seria, usando o conceito deleuziano de devir, "se desterritorializar em relação ao modelo. E quando Deleuze afirma que numa linha de fuga há sempre traição, isso significa trair as potências fixas, as significações dominantes, a ordem estabelecida - o que exige ser criador." (MACHADO, 2009, p. 214) Nas palavras de Deleuze e Guattari (1997, p. 18), o devir "não produz outra coisa senão ele próprio. É uma falsa alternativa que nos faz dizer: ou imitamos, ou somos." O devir é, portanto, "um rizoma, não é uma árvore classificatória nem genealógica." (p. 19). Ou seja, o devir não é fixo, fechado, portanto, pode-se dizer que ele é contra padrões majoritários da cultura, os devires minoritários e moleculares são capazes de desmontar representações, modelos. 
estar sempre a prestar contas à morte", sempre em alerta e prontos para correr gestos estes de desespero - na possibilidade de mais um respiro antes da morte de uma vida vivida na conformação de uma existência progressivamente inculcada, deteriorada, desgastada em que tanto faz viver, matar ou morrer: "Vida supérflua, portanto, cujo preço é tão baixo que não equivale a nada, nem sequer como mercadoria e, ainda menos, humana - é uma espécie de vida cujo valor está fora da economia, correspondendo apenas ao tipo de morte que se lhe inflige". Em grande medida, "o racismo é o motor do princípio necropolítico". (MBEMBE, 2017a, p. 28-30, 64-65).

Para Achinte (2009), a decolonialidade pode ser entendida como o processo por meio de que conhecemos outras histórias, trajetórias e formas de ser e estar no mundo, diferentemente da lógica racional do capitalismo contemporâneo, "humanizando la existencia en el sentido de devolver la dignidad a quienes por fuerza del proyecto hegemónico moderno/colonial fueron considerados inferiores o no-humanos." (p. 452). O fazer-poético nos encontro-saraus, no busão, nas esquinas, expressa o desejo e a invenção de uma outra forma de vida, uma forma de vida política diferente do medo, da inimizade e da guerra experimentadas na vida cotidiana.

O "Poeta Malandro" 22 é mais um dos poetas que está inventando territórios existenciais, procurando sobreviver no capitalismo contemporâneo financeiro. "Poeta Malandro" foi um dos primeiros poetas de busão e um dos que influenciaram outros poetas a recitar nos ônibus em Fortaleza, na época das ocupações das escolas em 2016. Atualmente, ele integra e é um dos idealizadores do ARMEM - Arte Revolucionária Marginal em Movimento -, iniciativa que reúne diversos artistas de periferia e suas múltiplas linguagens, desde poetas a malabaristas de rua. Quando perguntamos quais artistas compõem o Movimento, ele respondeu:

Cara, o favelado, né?! Já como diz, o próprio marginal, né?! Aquele que ele, às vezes ele não recebe a própria assistência do sistema, do Governo, desde educação, cultura, saúde... questão ali do saneamento básico. E a galera mesmo assim que encontra, vamos dizer assim, dentro dessa fuga da arte, encontra na realidade uma fuga através da arte, né?! Através da poesia, seja do break como eu conheço uma galera que dança no sinal que hoje se mantém através disso. Eu, mano Scooby, uma galera hoje também se mantém da poesia dentro dos coletivo e assim a gente tamo continuando, né?! (Poeta Malandro, poeta de busão, entrevista em 09 de outubro de 2018).

A re-existência dos poetas, seja por meio das práticas poéticas nos encontros-

22 Pseudônimo escolhido pelo poeta. 
saraus ou por meio da poesia no "busão" e outras linguagens, é um contínuo movimento de reinvenção, fuga e "salto" na própria existência: "Não sou prisioneiro da História. Não devo procurar nela o sentido do meu destino. Devo me lembrar, a todo instante, que o verdadeiro salto consiste em introduzir a invenção na existência. No mundo em que me encaminho, eu me recrio continuamente" (FANON, 2008, p. 189).

Só que chegou um momento da minha vida, cara, que eu lembro como se fosse ontem, sabe?! Ao lado do José Walter tem um canto chamado "Coliseu" que é um canto assim de cultura, né?! Que a galera se reunia e tudo. A galera se encontrava lá pra fumar um e também a galera vendia o seu bagui e eu não muito diferente chegava lá pra vender o meu. E um dia eu lembro como se fosse ontem que eu cheguei e tinha dois caras rimando improvisado e pra muita gente isso ali pode não ser nada, mas naquele momento aquele dois caras fazendo improviso eles me chamaram atenção, se intera?! E ao mesmo tempo que eu ia vender a droga, eu parei um momento e fui pro outro lado pra ver aquilo ali de interessante que caso contrário eu nunca tinha visto na minha vida assim ao vivo, né?! Porque eu já conhecia o improviso, já conhecia o rap, a questão da música, mas não assim tinha visto assim e sentido o impacto assim na hora e quando eu vi aquilo foi um impacto muito forte porque algo dentro de mim gritou assim: “Cara, eu quero isso pra minha vida!" E eu não sabia o que era, o que era o rap, o que era a poesia, eu desconhecia, tá ligado?! Aí foi a partir dos 16 anos que eu vim saber o que era uma poesia, o que era um poema, o que era um rap, que tipo: favela também tem arte, favelado também faz arte, tá ligado?! E com isso aí eu comecei a me instigar, tá ligado?! Buscar esse caminho, fui entrando devagarinho, fui botando o pé. Comecei na escola já. Na escola eu levava droga pra traficar e de repente quando eu comecei, já não ia mais vender droga, já ficava tirando onda, fazendo umas rima improvisada com a galera e eu via que a galera gostava e eu via que também que eu tinha facilidade pra fazer e também não só falar qualquer coisa, mas que eu sempre falava uma coisa massa, umas ideia massa por questão de ser muito ideológico, né?! Desde pivete eu vejo que eu sempre fui crítico. Então, essa questão também de ser só me ajudou muito porque me fez ter uma visão de tipo: às vezes as pessoas não te ajuda porque elas não te conhece. Mas é justamente dentro disso, às vezes não é porque você não conhece o outro que você não esteja precisando de ajuda ou que você não vá aceitar ajuda dele, entende? E aí, quando eu entrei nessa arte ela começou a me transformar, me modificar. De certo modo, vamos dizer, ela me matou, cara! Ela me matou e me fez assim renascer das cinzas, sabe?! Mas ela me fez renascer assim uma nova pessoa, com outro sentido, com outra visão. (Poeta Malandro, poeta de busão, entrevista em 09 de outubro de 2018). 
Foi por meio da rima improvisada (Batalha de $M C s$ ) em uma praça conhecida como "Coliseu", situada na terceira etapa do Bairro José Walter, em Fortaleza, que o Poeta Malandro introduziu a invenção na existência como outra forma de vida.

\section{Considerações finais}

Eu não luto para mudar o sistema não, mano! Eu luto para mudar as pessoas. Eu acho que se eu mudar as pessoas, eu modifico o sistema (Victor Oliveira, artista de rua e poeta de busão).

Os e as poetas de busão não recitam suas poesias somente para "iluminar um mundo que gostariam de 'ver melhor', não" (DIDI-HUBERMAN, 2011, p. 55), trata-se, antes de tudo, nessa travessia, de um "período estranho da história da humanidade", isto é, das "Políticas de inimizade" apontadas por Mbembe (2017a, p. 240), de mudar a si mesmo para, quem sabe, afetar aqueles que os cercam nessa "democracia de escravos". É nesse mesmo sentido que o poeta Reginaldo Figueiredo diz: "Eu escrevo um poema quando não sei o que fazer. Eu escrevo um poema e o poema me diz o que tenho que fazer". A necessidade de distinguir o que somos e, portanto, aquilo que somos no presente e o que vamos nos tornando.

Portanto, para "descolonizar" não basta resistir, é preciso re-existir. Em Fortaleza, considerada uma das cidades brasileiras e mundiais com maior índice de violência letal de adolescentes e jovens em sua maioria negras e negros, reinventar práticas de resistência e re-existências poéticas por intermédio da poesia no busão são táticas para permanecer vivo em face de processos de silenciamento, apagamento, morte simbólica e instrumentalmente, o que significa inventar espaços de sobrevivência e ocupação pedagógica das mentes - zonas móveis e temporárias.

Re-existir é criar outras possíveis formas de vida. Criar é re-existir. As táticas inventivas do fraco a favor da vida e da própria existência são, por si sós, um confronto no interior da rede social do poder. É daqui que surge a necessidade de pegar atalho, subverter e abrir minúsculas fendas na tomada de terreno (mesmo que de maneira sutil, silenciosa e contraditória). Não obstante, os e as poetas de busão são sujeitos mediadores e mediados pela possibilidade de exercício das práticas de re-existência: uma poética da "decolonialidade". 


\section{Referências}

ACHINTE, Adolfo Albán.

(2017). Prácticas creativas de re-existência basadas en lugar: más allá del arte... el mundo de lo sensible. Buenos Aires: Del Signo.

ACHINTE, Adolfo Albán.

(2009). Pedagogías de la re-existência: artistas indígenas y afrocolombianos. In: MIGNOLO, W. y PALERMO, Z. Arte y estética en la encrucijada descolonial. Buenos Aires: Del Signo.

AGIER, Michel.

(2015). Do refúgio nasce o gueto: antropologia urbana e política dos espaços precários. In: BIRMAN, Patrícia et al. Dispositivos Urbanos e Trama dos Viventes: ordens e resistências. Rio de Janeiro: FGV, pp. 33-53.

BARROS, et. al.

(2018). "Pacificação" nas Periferias: discursos sobre as violências e o cotidiano de juventudes em Fortaleza. In: Revista de Psicologia. Fortaleza: UFC, v.9. n.1, p. 117-128. Disponível em:

<http://www.periodicos.ufc.br/psicologiaufc/a rticle/view/30781>. Acesso em: 14 out. 2018.

BUTLER, Judith.

(2018). Corpos em Aliança e a Política das Ruas: Notas para uma teoria performativa de assembleia. Tradução de Fernanda Siqueira Miguens. Rio de Janeiro: Civilização Brasileira.

CERTEAU, Michel De.

(1994). A Invenção do Cotidiano: 1 artes de fazer. Tradução de Ephraim Ferreira Alves. Petrópolis: Vozes.

CLIFFORD, James.

(2014). A experiência etnográfica: antropologia e literatura no século XX. 4 ed. Rio de Janeiro: UFRJ.

CLIFFORD, James.

(2016). Introdução: Verdades parciais. In: CLIFFORD, James; MARCUS, George E. (0rg). A escrita da cultura: poética e política da etnografia. Tradução: Maria Claudia Coelho. Rio de Janeiro: EdUERJ; Papéis Selvagens Edições, pp. 31-61.
DELEUZE, Gilles.

(!996). O mistério de Ariana. Tradução e prefácio de Edmundo Cordeiro, Ed. Vega - Passagens. Lisboa.

DIDI-HUBERMAN, Georges.

(2011). Sobrevivência dos vaga-lumes. Tradução de Vera Casa Nova e Márcia Arbex, Belo Horizonte: UFMG.

FANON, Frantz.

(2008). Pele negra, máscaras brancas. Tradução de Renato da Silveira. Salvador: EDUFBA.

FOUCAULT, Michel.

(2013). 0 corpo utópico, as heterotopias. Tradução de Salma Tannus Muchail, São Paulo: n-1 Edições.

FREITAS, Geovani Jacó de.

(2003). Ecos da violência: narrativas e relações de poder no Nordeste canavieiro. Rio de Janeiro: Relum Dumará.

GLISSANT, Édouard.

(2011). Poética da Relação. Tradução de Manuela Ribeiro Sanches. Portugal: Porto.

GOFFMAN, Erving.

(2011). Ritual de Interação: ensaios sobre o comportamento face a face. Tradução de Fábio Rodrigues Ribeiro da Silva. 2. ed. Petrópolis: Vozes.

HARDT, Michael; NEGRI, Antonio.

(2001). Império. Tradução de Berilo Vargas. 2. ed. Rio de Janeiro: Record.

MBEMBE, Achille.

(2014). Crítica da Razão Negra. Tradução de Marta Lança. 2. ed. Lisboa: Antígona.

MBEMBE, Achille.

(2017a). Políticas da Inimizade. Tradução de Marta Lança. Lisboa: Antígona.

MBEMBE, Achille.

(2017b). A era do humanismo está terminando. Instituto Humanitas Unisinos. Disponivel em: $<$ http://www.ihu.unisinos.br/78- 
noticias/564255-achille-mbembe-a-era-dohumanismo-esta-terminando>. Acesso em: 28 out. 2018.

MBEMBE, Achille.

(2019). Sair da grande noite: ensaio sobre a África descoloniazada. Tradução de Fábio Ribeiro. Petrópolis, RJ: Vozes.

PAIVA, Luiz Fábio $S$.

(2019). "AQUI NÃO TEM GANGUE, TEM FACÇÃO": as transformações sociais do crime em Fortaleza, Brasil. Caderno C R H, Salvador, v. 32, n. 85, pp. 165-184, Jan./Abr.

PERELMAN, Mariano D.

(2017). Vender nos ônibus: Os buscas na cidade de Buenos Aires, Argentina. Tempo Social - Revista de sociologia da USP, v. 29, n. 1. Abril. Disponível em:

http://www.scielo.br/pdf/ts/v29n1/18094554-ts-29-01-0069.pdf>. Acesso em: 10 out.2017.

ROLNIK, Suely.

(2018). Esferas da insurreição: notas para uma vida não cafetinada. São Paulo: $\mathrm{n}-1$ edições.

SÁ, Leonardo Damasceno de; AQUINO, Jania Perla Diógenes de.

(2018). A "guerra das facções" no Ceará (20132018): socialidade armada e disposição viril para matar ou morrer. In: ENCONTRO ANUAL DA ANPOCS, 42., Caxambu. Anais Eletrônicos... Caxambu: ANPOCS, Disponivel em: <https://www.anpocs.com/index.php/papers40-encontro-3/gt-31/gt35-10/11420-aguerra-das-faccoes-no-ceara-2013-2018socialidade-armada-e-disposicao-viril-paramatar-ou-morrer/file> Acesso em: 12 mar. 2018.
SILVA, Francisco Rômulo do Nascimento.

(2019). Rede de Afetos: práticas de re-existências poéticas na cidade de Fortaleza (CE). $212 \mathrm{f}$. Dissertação (Mestrado em Sociologia) Programa de Pós-Graduação em Sociologia, Universidade Estadual do Ceará.

SOUZA, Ana Lúcia Silva.

(2009). Letramentos de Reexistência: culturas e identidades no movimento hip-hop. 206 f. Tese (Doutorado em Linguística Aplicada) - Instituto de Estudos da Linguagem, Universidade Estadual de Campinas, Campinas.

TELLES, Vera da Silva; HIRATA, Daniel Veloso.

(2007). Cidade e práticas urbanas: nas fronteiras incertas entre o ilegal, o informal e o ilícito. Estudos Avançados. v. 21, n. 61, pp. 173-191. Disponivel em: http://www.scielo.br/pdf/ea/v21n61/a12v216 1.pdf>. Acesso em: $11 \mathrm{fev} .2018$.

ZUMTHOR, Paul.

(2018). Performance, recepção, leitura. Tradução de Jerusa Pires Ferreira e Suely Fenerich. São Paulo: Ubu.

\section{Recebido em}

outubro de 2019

\section{Aprovado em}

abril de 2020 